\title{
USE OF FEED COLOR AND ODOR AS ATTRACTIVE TOOLS FOR MANAGING TURKEY CHICKS AT EARLY FEEDING
}

\author{
M. F. A. Farghly \\ Departent of Poultry Production, Faculty of Agriculture, University of Assiut, Assiut (71516), Egypt. \\ Email: farghly20002000@yahoo.com\&_farghly20002000@aun.edu.eg
}

(Received 29/5/2017, accepted 26/7/2017)

\section{SUMMARY}

\begin{abstract}
A total number of 180 one-day old unsexed native turkey chicks were chosen for evaluating the response of turkeys to different feed odors and colors on growth performance, carcass characteristics, some meat quality and health traits. Birds were allocated in three main groups ccording to feed odor (non-odor, molasses and fish odors) and then each main group was divided to two subgroups corresponded to non-colored and green colored feed, respectively. The findings indicated that birds fed diets of molasses or fish odors had significantly better values of body weight (BW), body weight gain (BWG), feed consumption (FC) and feed conversion ratio (FCR). Birds fed green color had heavier BW than those fed non color feed. BW, BWG and FC of birds fed green feed with molasses and fish odors significantly exceeded those of untreated feed at marketing age. No significant differences were found in each of some carcass traits, meat tender and juiciness due to feed odors, colors and their interactions. Liver percentage and meat flavor were increased in birds fed diets with molasses and fish odors than those of the non-odor group. Score of meat color was higher in birds fed green feed than those of the other group. Birds fed green feed with molasses or fish odor had the highest values of liver percentage, meat color and flavor scores. Plumage condition, H / L ratio and tonic immobility of turkeys fed green feed was significantly better than those of non-color group. No significant differences were found in plumage condition, body temperature, $\mathrm{H} / \mathrm{L}$ ratio and tonic immobility due to feed odors. Considering the improved performance, it could be concluded that the native turkeys prefer green feed with molasses or fish odors over traditional one. Finally, the feeding on green colored feeds with molasses or fish odors for turkeys during growing period may be recommended.
\end{abstract}

Keywords: feed odor, feed color, growth performance, carcass, meat quality, Turkey.

\section{INTRODUCTION}

Applying feeding protocol in post-hatched turkey chicks should avoid any managerial problems and produce birds with maximum body weight and the best feed conversion ratio. The early life of growing turkeys is considered crucial and needs special care to get them off to a good start (Farghly and Mahrose, 2017). Turkey chicks during post-hatch period are slow in learning to eat because weakened vision, so, starvation or dehydration and subsequent reduction in growth and increased mortality can occur if they couldn't find the feed easily. So, different trials have been made to overcome the adverse impacts arising from such problem on turkey chicks as well as the consequences on marketing performance. Early feed is desirable to enhance growth performance, productivity and development of the intestines and immune system (Jull-Madsen et al., 2004; Farghly and Abou-Kassem, 2014; Farghly and Mahrose, 2017; Farghly and Abdelfattah 2017) and improves the resistance of birds to pathogen agents (Uni and Ferket, 2004).

Aspects such as the color and odor of the feed appear to be likely feedback mechanisms. The latter can be used to create learned associations that can be employed to influence feed consumption in situations where the bird is allowed to be discriminatory in feed selection (Chadd, 2007). In study of bird DNA, Max-Planck-Gesellschaft, (2008) found genetic evidence that many species of bird have a highdeveloped sense of smell. Smell sense might indeed be considerable to birds compared to other animals, that some species of bird use their smell sense to navigate and distinguish individuals (Steiger et al., 2008). Birds have the ability to detect and respond adaptively to odors (Hagelin, 2007). The latter author made a distinction between environmentally derived odors as food and those produced by birds themselves as body odors or fecal odor. The response and any reaction to some odors at early ages appear 


\section{Farghly}

to be innate rather than learning tools (Amo et al., 2011). Steiger et al., (2008) reported smell in avian may be a more important sense than generally believed.

Sight senses is the most important for avian, and this is at least the received wisdom (Max-PlanckGesellschaft, 2008). Food recognition in poultry primarily involves vision and the recently hatched chicks have an innate preference for food of certain colors (Ferket and Gernat, 2006). One strategy is of interest, offering feed in different colors with attractive odors, which can call the attention of turkey chicks to detect the presence of offered feed rapidly. Indeed, when new feed is offered, chicks have a strong bias to use visual color in learning situations (Marples and Roper, 1996). Also, it is possible, that some feed colors might be attractive tools to baby chicks, to recondite and find feed early and reduce the incidence of starve-out (Cooper, 1971; Weeks et al., 1997; Khosravinia, 2007; Lecuellea, et al., 2010). To maximize the profit of turkey projects, the offered feed should be in green color (Farghly and Mahrose, 2017). In ostrich, chicks are being attracted to bright green foliage and a secondary response apparently being taste (Cilliers and Angel, 1999).

To the best of our knowledge, data on the effect of feed odors and colors and their interactions on FC and then performances of growing turkey chicks are scarce. Considering the importance of attractiveness of the offered diet on rapid feed access by turkey chicks, this study investigated various feed odors and colors which likely may increase growth performance and the final output.

\section{MATERIALS AND METHODS}

This experiment was conducted at the Research Poultry Farm, Poultry Production Department, Faculty of Agriculture, Assiut University, Assiut, Egypt. A total number of 180 one-day old unsexed native turkey chicks (local breed) were used in present study. Turkey chicks were divided into six equal treatments in a $3 \times 2$ factorial arrangement experiment ( 3 replicates of 10 chicks each). Birds were allocated in three main groups according to feed odor (non-odor, molasses and fish odors) and then each main group was divided into two sub-groups corresponded to non-colored feed and green colored feed, respectively. Vaccinations program were done according to the different stages of age under supervision of a licensed veterinarian. Coloring agent which added in the feed is healthy artificial colors, which usually supplemented to human feeds (produced by Star Aromatic Company, Bader city, Egypt, Mob; (0020201006907654), Tel fax; (0020228642136). Odor agents (natural molasses and fish odor sources) were hung in stock of feeders. All chicks had free access to fresh drinking water and given the experimental diet as presented in Table (1) from 0 to 16 weeks of age.

All birds were raised in floor pens $\left(2 \mathrm{~m}^{2}\right)$ under similar environmental and managerial conditions on deep litter floor of 7-8 cm thickness. During the first three days, all chicks were exposed to continuous lighting $(24 \mathrm{~h} /$ day); thereafter, the photoperiod was decreased gradually (one h/wk) until $12 \mathrm{hrs}$ lighting/day, with light intensity of 5-10 Lux.

Body weight (BW) was recorded on individual basis at $0,4,8,12$ and 16 weeks of age, besides mortality rate (\%) was recorded daily. Feed consumption (FC) was recorded, and body weight gain (BWG) as well as feed conversion ratio (FCR, g feed/g gain) were calculated monthly during the experimental period. Plumage condition was measured at 12 and 16 weeks of age, by evaluating the feather distribution over the body, using a scale from 1(completely feathered) to 5 (featherless). Body temperature $\left({ }^{\circ} \mathrm{C}\right)$ was estimated at 12 and 16 weeks of age, by using a thermometer inserted into the rectum for 2 minutes at a depth of $2 \mathrm{~cm}$ in midday. At 16 weeks of age, three birds per treatment were taken as representative samples and slaughtered. The carcass was dissected manually and the following criteria were recorded: carcass weight and dressing percentage ((carcass weight + giblets weight)/live body weight) x 100; weights of liver, heart, gizzard and abdominal fat. Sensory evaluation was carried out, in which a test panel consisting of five panelists judged the meat samples for color, flavor, tenderness, juiciness, and acceptability of broiler meat with grades of 10 points. The procedures of tonic immobility were described by Benoff and Siegel, (1976). Heterophil: lymphocyte (H/L) ratios cells were described by Campbell (1995).

\section{Statistical analysis:}

Data were subjected to ANOVA by applying the General Linear Model Procedure of SAS software (SAS Institute, version 9.2, 2009). Duncan (1955) was used to detect differences among means of different groups. The percentages of studied traits were transformed to Arcsin values. All data were analyzed using factorial design according to as the following model: 


$$
\mathrm{Y}_{\mathrm{ijk}}=\mu+\mathrm{G}_{\mathrm{i}}+\mathrm{M}_{\mathrm{j}}+(\mathrm{GM})_{\mathrm{ij}}+\mathrm{E}_{\mathrm{ijk}}
$$

Where: $\mathrm{Y}_{\mathrm{ijk}}=$ observation; $\mu$ = overall mean; $\mathrm{G}_{\mathrm{i}}=$ feed odor effect $(\mathrm{i}=1,2$ and 3$) ; \mathrm{M}_{\mathrm{j}}=$ feed color effect $(\mathrm{j}=1$ and 2$) ;(\mathrm{GM})_{\mathrm{ij}}=$ feed odor $\times$ feed color interaction; and $\mathrm{E}_{\mathrm{ijk}}=$ experimental error.

Table (1): Composition and calculated analysis of the experimental diet.

\begin{tabular}{lc}
\hline Ingredient & $(\%)$ \\
\hline Yellow corn & 60.0 \\
Soybean meal (44\%) & 19.0 \\
Concentrate & $20.0 *$ \\
Salt & 0.25 \\
Minerals mixture & 0.25 \\
Premix mixture & 0.50 \\
Total & 100 \\
& \\
Protein (\%) & 24.0 \\
ME (Kcal/ Kg) & 2900 \\
Crude fiber & 2.71 \\
Calcium (\%) & 1.61 \\
Available phosphorus ( \%) & 0.67 \\
\hline * Broiler concentrate contains: 52\% crude protein, 1.6\% crude fiber, 6.1\% ether extract, 7\% calcium, 3.5\% \\
available phosphorus , 1.5\% methionine, 2.1\% methionine and cystine, 3.0\% lysine and 2416 kcal/kg metabolizable \\
energy.
\end{tabular}

Each Kilogram of the broiler concentrate contains the following levels of vitamins and minerals: vit. A 130,000 IU; D3 26,000 IU; vit. E $120 \mathrm{IU}$; vit B12 $150 \mu \mathrm{g}$; vit. K3 MSB $16 \mu \mathrm{g}$; vit B2 $50 \mu \mathrm{g}$; capantothenate B3 $120 \mu \mathrm{g}$; nicotinic acid PP $250 \mu \mathrm{g}$; thiamine B1 $25 \mu \mathrm{g}$; folic acid $15 \mu \mathrm{g}$; pyridoxine B6 $15 \mu \mathrm{g}$; betain-Choline- $\mathrm{HCl}$

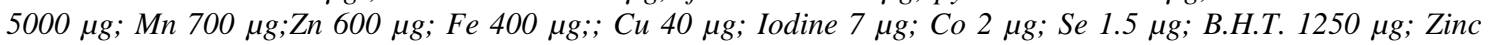
baciteracin $150 \mu g$.

** Calculated according to NRC (1994).

\section{RESULTS AND DISCUSSSION}

\section{Body weight (BW) and Body weight gain (BWG):}

The results presented in Table (2) showed significant differences $(\mathrm{P}<0.01)$ in $\mathrm{BW}$ and BWG as affected by feed odors at 12 and 16 weeks of age for BW, as well as at 8-12 and 12-16 weeks of age for BWG. Birds fed diets of molasses or fish odors had higher values of BW and BWG. Regarding feed color effect, insignificant differences ( $\mathrm{P}>0.05)$ in $\mathrm{BW}$ and $\mathrm{BWG}$ were observed, except at 16 weeks of age for BW. Group of birds fed green color had heavier BW than those fed non color feed. BW and BWG of birds fed green feed with molasses and fish odors significantly $(\mathrm{P} \leq 0.05)$ exceeded those of non-color and odor feed at 12 and 16 weeks of age (Table 2).

Supplementing feeds with colors or/ and odors during the first days particularly promotes BWG leading to increasing the marketing BW. Different feed odors and colors can affect tactile and visual cues in birds, which can lead to modifications in feed intake and growth (Farghly and Mahrose, 2017). Birds have the ability to detect and respond adaptively to odors (Hagelin, 2007), where the odor can affect avian food choice in different ways (Marples and Roper, 1997) and that might be the reason of increasing growth rate of turkeys fed green diet with molasses or fish odors in the current work. The results of this work showed that feed odor improved growth rate of turkeys. Our results were supported by those of Farghly et al. (2016a) who reported chicks fed on a commercial starter supplemented with molasses had higher BW and BWG than the control group. Also, Farghly et al. (2016b) indicated that birds fed feed with fish odor throughout the experimental period had superior BW and BWG when compared to those fed non-odor feed or feed with yolk odor. Feed with odors may contribute to improve the growth performance of turkey chicks via increasing early feed consumption during the first days of age, consequently the effects on the gastrointestinal tract and physiological functions of the digestive tract in broilers (Farghly and Glaal 2016). Also, the latter authors found that supplementing diets with odors of skim milk, molasses, fresh egg and fresh fish meat significantly $(\mathrm{P} \leq 0.05)$ increased $\mathrm{BW}$ and BWG as compared to the control group. Kabuage et al. (2000) indicated that the inclusion of molasses in broiler 


\section{Farghly}

diets resulted in heavier $(\mathrm{P} \leq 0.05) \mathrm{BW}$ of broilers at 8 weeks of age. Similar results were also obtained by Chee et al. (2010) who found that birds performed well as fed on a balanced diet contained molasses. The results of Bonos et al. (2010) revealed that the highest final BW was attained by birds fed on a diet supplemented with molasses.

Turkey birds exhibited short-term preferences for lighter colored feeds, at a free choice test (Chagneau et al., 2003). Color greatly affects the acceptability of the feed (Farghly and Mahrose, 2017). Farghly and Abou-kassem (2014) and Farghly and Mahrose (2017) found insignificant differences (P>0.05) in BW and BWG for all the feed color groups except at 14 and 16 weeks of age. Abdelfatah and Farghly (2016) and Farghly and Abdelfattah (2017) reported that birds fed yellow feed color had significantly the highest BW and BWG when compared to those of non-colored, red and green groups. On the other hand, broiler chicks were consistently gained more weight after 7 days when fed red colored feed rather than uncolored feed (Khosravinia, 2007). However, Retnani et al. (2009) and Farghly and Sharara (2016) found that coloring did not give the significant influence to BWG and final body weight.

Table (2): Body weight and daily body weight gain of native turkeys as affected by feed odor, color and their interactions

\begin{tabular}{|c|c|c|c|c|c|c|c|c|c|}
\hline \multirow{2}{*}{ Treatment } & \multicolumn{5}{|c|}{ Body weight (g, wks) } & \multicolumn{4}{|c|}{ Weight gain (g, wks) } \\
\hline & 0 & 4 & 8 & 12 & 16 & $0-4$ & $4-8$ & $8-12$ & $12-16$ \\
\hline \multicolumn{10}{|l|}{ Feed odor: } \\
\hline Non odor, $\mathrm{N}$ & 53.98 & 433.9 & 1058.2 & $1996.2^{\mathrm{b}}$ & $3194.4^{b}$ & 13.57 & 22.29 & $33.50^{\mathrm{b}}$ & $42.79^{b}$ \\
\hline Molasses, M & 53.78 & 442.3 & 1063.4 & $2073.1^{\mathrm{a}}$ & $3341.0^{\mathrm{a}}$ & 13.88 & 22.18 & $36.06^{\mathrm{a}}$ & $45.28^{a}$ \\
\hline Fish, F & 53.45 & 438.5 & 1074.0 & $2083.8^{\mathrm{a}}$ & $3378.4^{\mathrm{a}}$ & 13.75 & 22.70 & $36.06^{\mathrm{a}}$ & $46.24^{\mathrm{a}}$ \\
\hline SE & 3.94 & 45.98 & 82.06 & 122.91 & 193.76 & 1.54 & 2.30 & 3.37 & 5.16 \\
\hline$P$ value & 0.7559 & 0.6099 & 0.5589 & 0.0002 & 0.0001 & 0.552 & 0.432 & 0.0001 & 0.0010 \\
\hline \multicolumn{10}{|l|}{ Feed color: } \\
\hline Non color, $\mathrm{N}$ & 53.46 & 435.5 & 1053.2 & 2030.8 & $3276.7^{\mathrm{b}}$ & 13.65 & 22.06 & 34.91 & 44.50 \\
\hline Green, G & 54.02 & 440.9 & 1077.1 & 2071.2 & $3332.5^{\mathrm{a}}$ & 13.82 & 22.72 & 35.50 & 45.05 \\
\hline SE & 3.93 & 45.90 & 81.22 & 127.08 & 207.19 & 1.54 & 2.28 & 3.56 & 5.34 \\
\hline$P$ value & 0.3343 & 0.4377 & 0.0501 & 0.0644 & 0.0524 & 0.460 & 0.052 & 0.2677 & 0.4897 \\
\hline \multicolumn{10}{|c|}{ Color $\mathrm{X}$ odor interactions: } \\
\hline $\mathrm{NX} \mathrm{N}$ & 53.80 & 431.4 & 1044.8 & $1992.3^{\mathrm{c}}$ & $3181.2^{\mathrm{c}}$ & 13.49 & 21.91 & $33.84^{\mathrm{bc}}$ & $42.46^{\mathrm{c}}$ \\
\hline $\mathrm{NX} \mathrm{M}$ & 53.43 & 438.5 & 1044.1 & $2043.5^{\mathrm{bc}}$ & $3279.2^{b c}$ & 13.75 & 21.63 & $35.69^{\mathrm{a}}$ & $44.13^{\mathrm{bc}}$ \\
\hline N X F & 53.13 & 436.8 & 1070.8 & $2056.7^{\mathrm{bc}}$ & $3369.6^{\mathrm{ab}}$ & 13.70 & 22.64 & $35.21^{\mathrm{ab}}$ & $46.89^{a}$ \\
\hline $\mathrm{G} X \mathrm{~N}$ & 54.17 & 436.4 & 1071.5 & $2000.0^{c}$ & $3207.5^{\mathrm{c}}$ & 13.65 & 22.68 & $33.16^{\mathrm{c}}$ & $43.12^{b c}$ \\
\hline $\mathrm{G} \times \mathrm{M}$ & 54.13 & 446.1 & 1082.6 & $2102.7^{\mathrm{ab}}$ & $3402.8^{\mathrm{a}}$ & 14.00 & 22.73 & $36.43^{a}$ & $46.43^{a}$ \\
\hline G X F & 53.77 & 440.1 & 1077.3 & $2111.1^{\mathrm{a}}$ & $3387.3^{a}$ & 13.80 & 22.76 & $36.92^{\mathrm{a}}$ & $45.58^{a b}$ \\
\hline SE & 3.96 & 46.29 & 81.59 & 121.68 & 191.81 & 1.55 & 2.28 & 3.35 & 5.14 \\
\hline$P$ value & 0.9085 & 0.8957 & 0.2915 & 0.0003 & 0.0001 & 0.877 & 0.229 & 0.0001 & 0.0032 \\
\hline
\end{tabular}

\section{Feed consumption (FC) and feed conversion (FCR):}

The obtained results in Table (3) indicated insignificant differences in FC and FCR values due to feed colors, while significant differences in FC and FCR values due to feed odors, colors and their interactions. FC of birds fed green feed significantly increased than those of uncolored feed as well as birds fed green feed with fish odors significantly exceeded those of untreated feed with better FCR. The olfactory sense in birds may be more important in relation to feeding behavior than has generally been supposed (Marples and Roper, 1997). Some avian species can distinguish a variety of odors (Roper and Marples, 1997) and chicks can imprint onto an olfactory stimulus. It is believed that the color attracts newly hatched chicks to the feed; thereby encouraging them to eat more (Farghly and Mahrose, 2017). This could be considering as a useful technique for increasing FC and improving FCR of turkeys. Avian have higher visual or sighting capabilities compared with mammals (Chagneau et al., 2006), so birds depend mainly on the visual sense for obtaining information about food (Wenzel, 1971) but most potential foods have a recognizable odor as well as a characteristic appearance with which to attract or deter predators (Marples and Roper, 1997). A preference for green feed color over red one was observed in turkeys (Cooper, 1971), which is the reason to stimulate feed intake initiation of newly hatched chicks. Several possible mechanisms have been implicated in the control of appetite and feed intake of birds. Some of the signals 
reach at the cerebral cortex or hypothalamus and enhance those nerves that pass through the hypothalamus, from where other nerve networks transmit information to the organs of digestion and absorption (Farghly and Mahrose, 2017). These signals come directly from the food itself (color, shape and odor), whereas others originate from the intestinal tract following the ingestion of food (Ferket and Gernat, 2006). Hens discriminated colour more than shape when they had to choose between two objects (Dawkins and Woodington, 1997). One of the main three phases of feed intake is identifying the food using sensorial detection which follows by apprehending and then swallowing (Farghly and Mahrose, 2017). Lecuelle et al., (2011) concluded that a change in the feed color can induce a short-term decrease in FC, and the continuity in the color of feed could be a good way to lessen a reduce in feed consumption during a feed changeover. FC for orange feed color was decreased when compared to the yellow, red and green ones (Khosravinia, 2007) found that the. Weeks et al., (1997) and Farghly and Abdelfattah (2017) indicated that most of birds choose the yellow feed, when different colored feeds were introduced to them.

Table (3): Feed consumption and feed conversion ratio of native turkeys as affected by feed odor, color and their interactions.

\begin{tabular}{|c|c|c|c|c|c|c|c|c|}
\hline \multirow{2}{*}{ Treatment } & \multicolumn{4}{|c|}{ Feed consumption (g/bird/day, wks) } & \multicolumn{4}{|c|}{ Feed conversion $(\mathrm{g}, \mathrm{wks})$} \\
\hline & $0-4$ & $4-8$ & $8-12$ & $12-16$ & $0-4$ & $4-8$ & $8-12$ & $12-16$ \\
\hline \multicolumn{9}{|l|}{ Feed odor: } \\
\hline Non odor, $\mathrm{N}$ & $37.88^{b}$ & $77.48^{b}$ & 120.97 & $146.60^{b}$ & $2.79^{b}$ & 3.48 & 3.61 & 3.43 \\
\hline Molasses, M & $40.36^{\mathrm{a}}$ & $81.85^{\mathrm{a}}$ & 124.39 & $150.71^{\text {ab }}$ & $2.91^{\mathrm{ab}}$ & 3.69 & 3.45 & 3.33 \\
\hline Fish, F & $41.50^{\mathrm{a}}$ & $83.43^{\mathrm{a}}$ & 124.85 & $155.05^{\mathrm{a}}$ & $3.02^{\mathrm{a}}$ & 3.68 & 3.47 & 3.36 \\
\hline SE & 2.02 & 3.07 & 3.36 & 3.71 & 0.138 & 0.174 & 0.152 & 0.125 \\
\hline F value & 0.0209 & 0.0119 & 0.1269 & 0.0048 & 0.0397 & 0.089 & 0.1659 & 0.3865 \\
\hline \multicolumn{9}{|l|}{ Feed color: } \\
\hline Non color, $\mathrm{N}$ & 38.94 & 79.95 & 121.98 & 148.91 & 2.85 & 3.63 & 3.50 & 3.35 \\
\hline Green, G & 40.88 & 81.89 & 124.82 & 152.67 & 2.96 & 3.61 & 3.52 & 3.39 \\
\hline SE & 2.31 & 3.86 & 3.42 & 4.73 & 0.156 & 0.198 & 0.165 & 0.128 \\
\hline F value & 0.0941 & 0.3020 & 0.0971 & 0.1113 & 0.1762 & 0.848 & 0.7385 & 0.5192 \\
\hline \multicolumn{9}{|c|}{ Color $\mathrm{X}$ odor interactions: } \\
\hline N X N & $36.60^{b}$ & $76.96^{\mathrm{b}}$ & $118.77^{\mathrm{b}}$ & $144.11^{\mathrm{c}}$ & 2.72 & 3.51 & $3.51^{\mathrm{ab}}$ & 3.4 \\
\hline $\mathrm{NX} \mathrm{M}$ & $39.39^{\mathrm{ab}}$ & $80.70^{a b}$ & $122.66^{\mathrm{ab}}$ & $147.77^{\mathrm{c}}$ & 2.87 & 3.73 & $3.44^{\mathrm{ab}}$ & 3.35 \\
\hline $\mathrm{NXF}$ & $40.84^{\mathrm{a}}$ & $82.18^{a b}$ & $124.52^{\mathrm{ab}}$ & $154.85^{\mathrm{ab}}$ & 2.98 & 3.63 & $3.54^{\mathrm{ab}}$ & 3.3 \\
\hline $\mathrm{G} \times \mathrm{N}$ & $39.15^{\mathrm{ab}}$ & $78.00^{\mathrm{b}}$ & $123.18^{\mathrm{ab}}$ & $149.10^{\mathrm{bc}}$ & 2.87 & 3.44 & $3.72^{\mathrm{a}}$ & 3.46 \\
\hline $\mathrm{G} \times \mathrm{M}$ & $41.33^{\mathrm{a}}$ & $83.00^{a b}$ & $126.12^{\mathrm{a}}$ & $153.64^{\mathrm{ab}}$ & 2.95 & 3.66 & $3.46^{\mathrm{ab}}$ & 3.31 \\
\hline $\mathrm{G} \times \mathrm{F}$ & $42.16^{\mathrm{a}}$ & $84.67^{\mathrm{a}}$ & $125.18^{\mathrm{a}}$ & $155.25^{\mathrm{a}}$ & 3.06 & 3.72 & $3.39^{\mathrm{b}}$ & 3.41 \\
\hline SE & 1.89 & 3.19 & 3.18 & 3.13 & 0.139 & 0.188 & 0.144 & 0.133 \\
\hline F value & 0.0417 & 0.0513 & 0.1514 & 0.0046 & 0.1288 & 0.395 & 0.0528 & 0.6924 \\
\hline
\end{tabular}

The improvement in FCR at late ages, noted with the use of feed odors may be due to improving FC at early ages, consequently length and weight of the gizzard, intestine, proventriculus, liver and pancreas increase in the first days of the age (Nitsan et al., 1991a). Digestion and absorption of nutrients in early age rely on pancreatic enzyme activity (Nitsan et al., 1991b). Pancreatic enzymatic reserve in the baby chick (at hatching) such as trypsin, chymotrypsin, amylase and lipase is weak. These secretions stimulated by feed intake dramatically, which are observed in the first days of age (Jull-Madsen et al., 2004). Domestic chicks show enhanced neophobia towards odors that are linked with chemical defense and the birds innately avoid odors that are naturally associated with danger (Marples and Roper, 1996). The latter authors indicated that none of the odors used (2-methoxy-3-sec-butyl pyrazine, 2-methoxy-3isobutyl pyrazine, almond oil, vanilla oil and thiazole) seemed to be intrinsically aversive. The odors used in the current work are considering examples of adaptive olfactory responses to environmental odors. Our obtained results were in agreement with the findings achieved by Farghly et al., (2016a) who found that feed with molasses had little effect on FC on birds than for those fed control diet. Farghly et al. (2016b) showed that birds fed feed with fish odor throughout the experimental period had superior FCR values as compared with birds fed non-odor feed or feed with yolk odor. Molasses and fish odors feed have been shown to improve FCR by up to main points, possibly due to an increased palatability. The results of feed 


\section{Farghly}

efficiency as affected by feed odors are in agreement with the findings of Farghly and Glaal (2016) who found that feed odor influenced FCR in broilers.

Abdel Rahman (1984) revealed that the increase in FC of broiler chicks could be attributed to the palatability effect of molasses. Men and Su (1992) found that FCR was satisfactory by early supplementing the duck diets with molasses diets. However, Kabuage et al., (2000) found non-significant effects in FC and FCR due to inclusion of molasses in broilers. In agreement with our results, several investigations indicated that colored feed did not significantly change FC and FCR (Lecuellea et al., 2010; Farghly and Abou-kassem, 2014; Farghly and Sharara, 2016 and Farghly and Mahrose, 2017). In contrast, Abdelfatah and Farghly (2016) and Farghly and Abdelfattah (2017) reported that feed color treatments significantly changed FC and FCR of broilers. The improvement in FCR at late ages, noted with the use of feed odors may be due to improving FC at early ages, consequently length and weight of the gizzard, intestine, proventriculus, liver and pancreas increase in the first days of the age (Nitsan et al., 1991a). Digestion and absorption of nutrients in early age rely on pancreatic enzyme activity (Nitsan et al., 1991b). Pancreatic enzymatic reserve in the baby chick (at hatching) such as trypsin, chymotrypsin, amylase and lipase is weak. These secretions stimulated by feed intake dramatically, which are observed in the first days of age (Jull-Madsen et al., 2004). Domestic chicks show enhanced neophobia towards odors that are linked with chemical defense and the birds innately avoid odors that are naturally associated with danger (Marples and Roper, 1996). The latter authors indicated that none of the odors used (2-methoxy-3-sec-butyl pyrazine, 2-methoxy-3-isobutyl pyrazine, almond oil, vanilla oil and thiazole) seemed to be intrinsically aversive. The odors used in the current work are considering examples of adaptive olfactory responses to environmental odors. Our obtained results were in agreement with the findings achieved by Farghly et al., (2016a) who found that feed with molasses had little effect on FC on birds than for those fed control diet. Farghly et al. (2016b) showed that birds fed feed with fish odor throughout the experimental period had superior FCR values as compared with birds fed non-odor feed or feed with yolk odor. Molasses and fish odors feed have been shown to improve FCR by up to main points, possibly due to an increased palatability. The results of feed efficiency as affected by feed odors are in agreement with the findings of Farghly and Glaal (2016) who found that feed odor influenced FCR in broilers.

Abdel Rahman (1984) revealed that the increase in FC of broiler chicks could be attributed to the palatability effect of molasses. Men and Su (1992) found that FCR was satisfactory by early supplementing the duck diets with molasses diets. However, Kabuage et al., (2000) found non-significant effects in FC and FCR due to inclusion of molasses in broilers. In agreement with our results, several investigations indicated that colored feed did not significantly change FC and FCR (Lecuellea et al., 2010; Farghly and Abou-kassem, 2014; Farghly and Sharara, 2016 and Farghly and Mahrose, 2017). In contrast, Abdelfatah and Farghly (2016) and Farghly and Abdelfattah (2017) reported that feed color treatments significantly changed FC and FCR of broilers.

\section{Carcass characteristics and meat quality traits:}

No significant differences $(\mathrm{P}>0.05)$ were found neither in carcass traits nor in meat quality due to feed odors, colors and their interaction, except in liver percentage, meat color and flavor (Table 4). Liver percentage and meat flavor were increased in birds fed diets with molasses and fish odors than those of the non-odor group (Table 4). Score of meat color was higher in birds fed green feed than those of the other group. Birds fed green feed with molasses or fish odor had the highest values of liver percentage and meat color and flavor scores (Table 4).

In consistency with the present findings, Farghly et al. (2016b) showed insignificant differences in all carcass traits. In contrast, Farghly et al. (2016a) indicated that carcass traits of the birds fed on a starter ration supplemented with molasses were relatively higher than those of the control group. Farghly and Glaal (2016) reported that molasses and fresh fish supplementation broilers had superior dressed carcass, gizzard and liver percentages. Incorporation of high levels of molasses generally induced the same previously mentioned changes due to the improvement in the digestive organs and induced slight increases in liver and viscera weights (Alvarez, $1976 \mathrm{a}$ and b). Abdel Rahman (1984) reported that dietary molasses did not affect dressing percentage. Bonos et al. (2010) reported that dietary molasses significantly $(\mathrm{P} \leq 0.05)$ decreased liver percentage, but had no effect on dressing percentage.

The current results are on the same line with those of Farghly and Abou-kassem (2014) and Farghly and Mahrose (2017) who showed insignificant differences in the percentages of dressed carcass, heart, liver, gizzard and abdominal fat as well as, most of the meat quality traits due to different feed colors. On contrary, Abdelfatah and Farghly (2016) and Farghly and Abdelfattah (2017) found that feed color significantly influenced carcass, liver and gizzard percentages of broiler chicks. 
Egyptian J. Nutrition and Feeds (2017)

Table (4): Carcass and meat quality of native turkeys as affected by feed odor, color and their interactions.

\begin{tabular}{|c|c|c|c|c|c|c|c|c|c|}
\hline \multirow{2}{*}{ Treatment } & \multicolumn{5}{|c|}{ Carcass traits $(\%)$} & \multicolumn{4}{|c|}{ Meat quality score } \\
\hline & Dressed & Heart & Liver & Gizzard & Fat & Color & Flavor & Tender & Juiciness \\
\hline \multicolumn{10}{|l|}{ Feed odor: } \\
\hline Non odor, $\mathrm{N}$ & 75.50 & 0.24 & $1.97^{\mathrm{b}}$ & 2.31 & 1.81 & 7.83 & $7.80^{\mathrm{b}}$ & 8.00 & 7.93 \\
\hline Molasses, $\mathrm{M}$ & 76.30 & 0.24 & $2.30^{\mathrm{a}}$ & 2.59 & 1.92 & 8.00 & $8.30^{\mathrm{a}}$ & 8.03 & 8.10 \\
\hline Fish, F & 75.86 & 0.23 & $2.35^{\mathrm{a}}$ & 2.51 & 1.87 & 8.00 & $8.07^{\mathrm{ab}}$ & 8.13 & 8.03 \\
\hline SE & 1.44 & 0.02 & 0.22 & 0.37 & 0.41 & 0.87 & 0.75 & 0.82 & 0.76 \\
\hline F value & 0.6332 & 0.9834 & 0.0195 & 0.4199 & $\begin{array}{c}0.900 \\
7\end{array}$ & 0.6957 & 0.0402 & 0.8069 & 0.6913 \\
\hline Feed color: & & & & & & & & & \\
\hline $\begin{array}{l}\text { Non color, N } \\
\text { Green. G }\end{array}$ & $\begin{array}{l}75.45 \\
76.33\end{array}$ & $\begin{array}{l}0.23 \\
0.24\end{array}$ & $\begin{array}{l}2.14 \\
2.27\end{array}$ & 2.37 & $\begin{array}{l}1.81 \\
1.92\end{array}$ & $\begin{array}{l}7.40^{\mathrm{b}} \\
8.38^{\mathrm{a}}\end{array}$ & $\begin{array}{l}7.98 \\
8.13\end{array}$ & $\begin{array}{l}8.04 \\
8.07\end{array}$ & $\begin{array}{l}8.00 \\
8.04\end{array}$ \\
\hline SE & 1.36 & $\begin{array}{l}0.24 \\
0.02\end{array}$ & 0.27 & $\begin{array}{l}2.37 \\
0.36\end{array}$ & $\begin{array}{l}1.92 \\
0.39\end{array}$ & $\begin{array}{l}8.38 \\
0.72\end{array}$ & $\begin{array}{l}0.15 \\
0.77\end{array}$ & $\begin{array}{l}0.01 \\
0.82\end{array}$ & $\begin{array}{l}0.04 \\
0.75\end{array}$ \\
\hline F value & 0.1877 & 0.6042 & 0.3367 & 0.2417 & $\begin{array}{c}0.568 \\
8\end{array}$ & 0.0001 & 0.3406 & 0.8976 & 0.7802 \\
\hline \multicolumn{10}{|c|}{ Color X odor interactions: } \\
\hline NX N & 75.12 & 0.23 & $1.98^{\mathrm{bc}}$ & 2.22 & 1.78 & $7.33^{\mathrm{b}}$ & $7.73^{\mathrm{b}}$ & 7.93 & 8.00 \\
\hline NX M & 75.67 & 0.23 & $2.19^{\mathrm{bc}}$ & 2.44 & 1.76 & $7.60^{\mathrm{b}}$ & $8.13^{\mathrm{ab}}$ & 8.20 & 8.00 \\
\hline NX F & 75.55 & 0.23 & $2.26^{\mathrm{ab}}$ & 2.44 & 1.91 & $7.27^{\mathrm{b}}$ & $8.07^{\mathrm{ab}}$ & 8.00 & 8.00 \\
\hline GX N & 75.87 & 0.24 & $1.96^{\mathrm{c}}$ & 2.4 & 1.85 & $8.33^{\mathrm{a}}$ & $7.87^{\mathrm{ab}}$ & 8.07 & 7.87 \\
\hline G X M & 76.93 & 0.24 & $2.41^{\mathrm{ab}}$ & 2.75 & 2.08 & $8.40^{\mathrm{a}}$ & $8.47^{\mathrm{a}}$ & 7.87 & 8.20 \\
\hline GX F & 76.18 & 0.24 & $2.45^{\mathrm{a}}$ & 2.58 & 1.83 & $8.40^{\mathrm{a}}$ & $8.07^{\mathrm{ab}}$ & 8.27 & 8.07 \\
\hline $\mathrm{SE}$ & 1.51 & 0.02 & 0.23 & 0.39 & 044 & 0.73 & 0.76 & 0.82 & 0.76 \\
\hline F value & 0.764 & 0.99 & 0.091 & 0.691 & 0.95 & 0.0001 & 0.0551 & 0.7546 & 0.9090 \\
\hline
\end{tabular}

\section{Health and physiological aspects:}

The data found in Table (5) showed that the differences in plumage conditions, H / L Ratio and tonic immobility among the experimental groups were significant $(\mathrm{P} \leq 0.05)$ as affected by feed color than those of non-color group. The average of plumage conditions of birds fed green feed was significantly $(\mathrm{P} \leq 0.05)$ lower than those of non-color group. No significant differences $(\mathrm{P}>0.05)$ were found in body temperature and plumage conditions among the experimental groups due to the effects of feed odors, colors and their interactions. While, $\mathrm{H} / \mathrm{L}$ Ratio and tonic immobility of birds fed diets with odors and their interactions with colors. Mortality rates of the studied treatments ranged between 0.00 to $10.00 \%$.

The current results of feed odors are in close agreement with the previous outcomes of Farghly and Glaal (2016) who showed insignificant differences in plumage condition and mortality rate. Farghly et al. (2016a) found that mortality rate of the chicks fed on a starter ration supplemented with molasses was decreased as compared to those of the control group. Also, Farghly et al. (2016b) reported that broilers fed feed with molasses and fish odors throughout the experimental period had superior livability percentages as compared to those fed non-odor feed or feed with yolk odor. Otherwise, the latter authors concluded that no significant differences were existed in plumage condition values. However, Pérez and San Sebastian (1970) found no apparent health problems due to the use of molasses. Farghly and Aboukassem (2014) found that feed color insignificantly affects values of H / L ratio. Also, Farghly and Abdelfattah (2016) observed that birds fed red colored feed had significant high value of tonic immobility.

Immunity starts to develop during the embryogenesis and continues for the first days of age. Useful impacts of early nutrition could be heightened through improving immune system and resistance of birds to pathogen agents (Uni and Ferket, 2004). Feed provides nutrients for the growth and development of both primary and secondary lymphoid organs (Farghly and Mahrose, 2017). Immunity of baby chicks at hatch, digestive system needs feeding for rapid development, especially the mucosal immune system. It has been found that delayed feeding impairs the intestinal development as well as development of the gutassociated lymphoid tissues like bursa of Fabricius and cecal tonsils. So, delayed feeding directly suppresses immunity (Jull-Madsen et al., 2004), and in turn, colored feed enhances turkey chicks to eat and keep livability. The current findings are in consistency with those of Farghly and Abou-kassem 


\section{Farghly}

(2014) and Farghly and Mahrose (2017) who found insignificant differences in plumage condition among the experimental feed color groups. Also, results of Farghly and Mahrose (2017) regarding the effect of feed color on body temperature did not reach the significance level. In contrast, Farghly and Aboukassem (2014) observed that the differences in body temperature among the experimental feed color groups were significant; where the average body temperature of green feed group was significantly $(\mathrm{P} \leq 0.05)$ lower than those of red and non-color groups. Farghly and Mahrose (2017) and Farghly and Abdelfattah (2017) found comparable findings with the present results, where mortality rate of the studied feed color groups ranged between 3.33 and $6.66 \%$.

Table (5): Plumage condition, body temperature, and mortality rate of native turkeys as affected by feed odor, color and their interactions

\begin{tabular}{|c|c|c|c|c|c|}
\hline Treatment & $\begin{array}{l}\text { Plumage } \\
\text { conditions }\end{array}$ & Body temperature & $\begin{array}{l}\mathrm{H} / \mathrm{L} \\
\text { Ratio }\end{array}$ & Tonic immobility & Mortality rate \\
\hline \multicolumn{6}{|l|}{ Feed odor: } \\
\hline Non odor, $\mathrm{N}$ & 1.80 & 41.62 & 0.44 & 1.67 & 8.33 \\
\hline Molasses, M & 1.67 & 41.61 & 0.39 & 1.65 & 8.33 \\
\hline Fish, F & 1.67 & 41.57 & 0.44 & 1.80 & 3.33 \\
\hline SE & 0.70 & 0.81 & 0.040 & 0.083 & -- \\
\hline $\mathrm{F}$ value & 0.6938 & 0.9897 & 0.276 & 0.374 & -- \\
\hline \multicolumn{6}{|l|}{ Feed color: } \\
\hline Non color, $\mathrm{N}$ & $1.89^{\mathrm{a}}$ & 41.58 & $0.45^{\mathrm{a}}$ & $1.79^{\mathrm{a}}$ & 5.56 \\
\hline Green, G & $1.53^{\mathrm{b}}$ & 41.61 & $0.38^{\mathrm{b}}$ & $1.61^{\mathrm{b}}$ & 7.78 \\
\hline SE & 0.67 & 0.80 & 0.030 & 0.078 & -- \\
\hline $\mathrm{F}$ value & 0.0138 & 0.8954 & 0.0425 & 0.0482 & -- \\
\hline \multicolumn{6}{|c|}{ Color X odor interactions: } \\
\hline $\mathrm{NX} \mathrm{N}$ & 2.07 & 41.70 & $0.48^{\mathrm{a}}$ & $1.74^{\mathrm{ab}}$ & 6.67 \\
\hline NX M & 1.80 & 41.50 & $0.42^{\mathrm{ab}}$ & $1.61^{\mathrm{b}}$ & 10.00 \\
\hline NX F & 1.80 & 41.55 & $0.48^{\mathrm{a}}$ & $1.86^{\mathrm{a}}$ & 0.00 \\
\hline G X N & 1.53 & 41.54 & $0.40^{\mathrm{ab}}$ & $1.58^{\mathrm{b}}$ & 10.00 \\
\hline G X M & 1.53 & 41.71 & $0.35^{\mathrm{b}}$ & $1.56^{\mathrm{b}}$ & 6.67 \\
\hline $\mathrm{G} \mathrm{X} \mathrm{F}$ & 1.53 & 41.60 & $0.40^{\mathrm{ab}}$ & $1.73^{\mathrm{ab}}$ & 6.67 \\
\hline SE & 0.68 & 0.84 & 0.031 & 0.081 & -- \\
\hline F value & 0.1880 & 0.9966 & 0.0341 & 0.0352 & -- \\
\hline
\end{tabular}

\section{CONCLUSION}

It could be concluded from the current study that the native turkey chicks prefer green feed with molasses or fish over traditional feed. Access to feed in green color with molasses or fish odors after hatch exhibited obvious effects on growth performance. Consequently, feeds for turkey chicks should be in green color with molasses or fish odors during growing period. Finally, the feeding on green colored feeds with molasses or fish odors for turkey chicks may be recommended.

\section{REFERENCES}

Abdel Rahaman, H., (1984). The effect of various levels of molasses and vegetable oil (Sesame) on performance and carcass characteristics of broilers chicks. M.Sc. Thesis, Faculty of Agriculture University of Khartoum.

Abdelfattah, M.G. and M.F.A. Farghly, (2016). Effect of feed color on growth performance of broilers. The $17^{\text {th }}$ Conference of the Egyptian Society of Animal Production on Sustainable Livestock Development: Challenges and Opportunities, 10-13 October, Sharm El-Sheikh, Egypt (Abstract).

Alvarez, R.J. (1976b). Morphologic traits of the digestive tract of chickens fed final molasses diets. Cuban J. Agric. 10: 298-305. 
Alvarez, R.J., (1976a). A note on the rate of passage of digesta in chicken fed levels of final molasses. Cuban J. Agric. Sci. 10: 169-178

Amo, L., Visser, M.E. and K., van Oers, (2011). Smelling out predators is innate in birds. Ardea 99: 177184.

Benoff, F. H., and P. B. Siegel (1976). Genetic analyses of tonic immobility in young Japanese quail (Coturnix coturnix japonica). Anim. Learn. Behav. 67:226-231.

Bonos, M. Eleftherios., V. Efterpi Christaki C. Panagiota and Florou-Paneri (2010). Effect of Dietary Supplementation of Mannan Oligosaccharides and Acidifier Calcium Propionate on the Performance and Carcass quality of Japanese quail (Coturnix japonica) Int. J. of Poult. Sci. 9: 264-272.

Campbell, T.W. (1995). Avian Hematology and Cytology, (Ames, Iowa, Iowa State University Press).

Chadd, S., (2007). Future trends and developments in poultry nutrition. In: Poultry in the $21^{\text {st }}$ Century: Avian Influenza and Beyond. Paper presented at: Proceedings of the International Poultry Conference, Bangkok, Thailand, 5-7 November, pp: 269-297.

Chagneau, A.M., Laviron, F., Lamy, S., Bouvarel, I., Picard, M., Lessire, M. and P., Lescoat (2006). Short-Term number of pecks and feed intake levels: A link with the physical characteristics of feed in four-week-old turkeys. Poultry Science 85: 923-931.

Chagneau, A.M., Penaud, L. Bouvarel, I., Lessire, M., and M., Picard, (2003). Does the colour of the feed influence the choice of the turkeys? Spring Meeting of the WPSA French Branch Meeting.

Chee, S.H., Iji, P.A., Choct, M., Mikkelsen, L.L., and A., Kocher, (2010). Characterization and response of intestinal microflora and mucins to manano-oligosaccharide and antibiotic supplementation in broiler chickens. British Poultry Science 51: 368-380.

Cilliers, S.C. and C.R.,Angel, (1999). Basic concepts and recent advances in digestion and nutrition. The Ostrich, Biology, Production and Health, edited by D.C. Deeming, CABI publishing.

Cooper, J.B., (1971). Colored feed for turkey poults. Poultry Science 50: 1892-1893.

Dawkins, S.M. and A., Woodington, (1997). Distance and the presentation of visual stimuli to birds. Animal Behaviour 54: 1019-1025.

Duncan, D.B., (1955). Multiple range and multiple F test. Biometrics 11, 1-42.

Farghly M. F. A. and M. G. Abdelfattah (2017). Growth performance and carcass characteristics of broilers as affected by feed color. Egyptian Journal of Animal Science, (under publish).

Farghly M.F.A. and A.E., Glaal, (2016). Effect of dietary natural odor and flavor sources in early feeding on broilers performance. Paper presented at: The $17^{\text {th }}$ Conference of the Egyptian Society of Animal Production on Sustainable Livestock Development: Challenges and Opportunities, October 10-13, Sharm El-Sheikh, Egypt (Abstract).

Farghly M.F.A., El-Hammady, H.Y., Madian, A.H. and S.F., Ahmed (2016b). Impact of early dietary supplementing with some performance promoters on the production of Japanese quail. Paper presented at: The $17^{\text {th }}$ Conference of the Egyptian Society of Animal Production on Sustainable Livestock Development: Challenges and Opportunities, October 10-13, Sharm El-Sheikh, Egypt (Abstract).

Farghly, M.F., and Kh.M., Mahrose, (2017). The response of growing native turkeys to different feed colours and forms. Journal of Animal Physiology and Animal Nutrition DOI: 10.1111/jpn.12703

Farghly, M.F.A. and D.E., Abou-Kassem, (2014). Impacts of feed color and form on growth performance of local turkey. Egyptian Journal of Nutrition and Feeds 17, 537-547.

Farghly, M.F.A., Abouelezz F.M.K., Abdelnabi, M.A. and M.M., Kotb, (2016a). Effect of feed odor on growth performance and carcass characteristics of local turkey. Paper presented at: The $9^{\text {th }}$ International Poultry Conference, 7 - 10 November, 2016, Hurghada, Egypt (Abstract).

Farghly, M.F.A., and H.H., Sharara, (2016). Effect of feed and feeder color on growth performance and carcass characteristics of local turkey. Paper presented at: The $9^{\text {th }}$ International Poultry Conference, 7 - 10 November, 2016, Hurghada, Egypt (Abstract).

Ferket, P.R. and A.G., Gernat, (2006). Factors that affect feed intake of meat birds: A review. International Journal of Poultry Science 5, 905-911. 


\section{Farghly}

Hagelin, J.C., (2007). Odors and chemical signaling. In: Jamieson, B.G.M. (Ed.), Reproductive Biology and Phylogeny of Birds, vol. 6B. Science Publishers, Enfield, NH, pp: 75-119.

Jull-Madsen, H.R., Su, G. and P., Sorensen, (2004). Influence of early or late start of first feeding on growth and immune phenotype of broilers. British Poultry Science 45: 210-222.

Kabuage, L.W., Mbugua, P.N., Mitaru, B.N. and T.A., Ngatia, (2000). Effect of steam pelleting and inclusion of molasses in amaranth diets on broiler chicken performance, carcass composition and histopathology of some internal organs. International Journal of Poultry Science 2: 161-164

Khosravinia, H., (2007). Preference of broiler chicks for color of lighting and feed. Poultry Science 44: 213-219.

Lecuelle, S., Bouvarel, I., Chagneau, A., Laviron, F., Lescoat, P. and C., Leterrier, (2011). Early visual experience of food does not appear to reduce subsequent feed neophobia in turkeys. Poultry Science 90: $1-9$.

Lecuelle, S., Bouvarel, I., Chagneau, A., Lescoat, P., Laviron, F. and C., Leterrier, (2010). Feeding behaviour in turkeys with a change-over from crumbs to pellets. Applied Animal Behaviour Science 125: $132-142$.

Marples, N.M. and T.J., Roper, (1996). Effects of novel colour and smell on the response of naive chicks towards food and water. Animal Behaviour 51: 1417-1424.

Marples, N.M. and T.J., Roper, (1997). Response of domestic chicks to methyl anthranilate odour. Animal Behaviour 53: 1263-1270.

Max-Planck-Gesellschaft (2008). Birds Have A Good Sense Of Smell. ScienceDaily. Retrieved March 25, 2017 from www.sciencedaily.com/releases/2008/07/080716111421.htm

Men, B.X. and V.V., Su, (1992). Sugar sugarcane products in diets of ducks. Livestock Research for Rural Development 4: 10-14.

Nitsan, Z., Avraham, G.B., Zoref, Z. and I., Nir, (1991a). Growth and development of the digestive organs and some enzymes in the broiler chick after hatching. British Poultry Science 32: 515-523.

Nitsan, Z., Dunnington, E.A. and P.B. Siegel, (1991b). Organ growth and digestive enzyme levels to 15 days of age in lines of chickens differing in body weight. International Journal of Poultry Science 70: 2040-2048.

NRC, (1994). Nutrient Requirements of Poultry. $9^{\text {th }}$ rev. ed., National Research Council, National Academy Press, Washington, D.C.

Pérez, R. and J.R., San Sebastian, (1970). Liquid molasses-based diets for ducks. Revista Cubana de Ciencia Agrícola 4: 205-207.

Retnani, Y., Suprapti, E., Firmansyah, I, Herawati, L. and R.,Mutia, (2009). Effect of coloring agent addition in the broiler chicken rations on performance, percentage of bursa of Fabricius, carcass and viscera. Journal of the Indonesian Tropical Animal Agriculture 34: 115-121.

Roper, T.J. and N.M., Marples, (1997). Odour and colour as cues for taste-avoidance learning in domestic chicks. Animal Behaviour 53: 1241-1250.

SAS, 2009: SAS User's Guide, statistics. 9.2 ${ }^{\text {th }}$ ed., Cary NC, SAS Institute Inc.

Steiger, S.S., Fidler, A.E., Valcu, M. and B., Kempenaers (2008). Avian olfactory receptor gene repertoires: evidence for a well-developed sense of smell in birds? Proceedings of the Royal Society B 275: 2309-2317.

Uni, Z. and P.R., Ferket, (2004). Methods of early nutrition and their potential. World's Poultry Science Journal 60: 101-111.

Weeks, C.A., C. Brooks, G. Coe and T.C (1997). Danbury, Effect of food and feeder colour on food consumption of young layers and broilers, British Poultry Science 38: S17.

Wenzel, B.M., (1971). Chemical senses I: Olfaction. In: Handbook of Sensory Physiology, Ed. by L. M. Beidler, pp:433-448. Berlin: Springer-Verlag.

Yalda, A.Y. and J.M., Forbes, (1995). Food intake and growth in chicks given food in the wet form with and without drinking water. British Poultry Science 36: 357-369. 


\title{
استخدام لون ورائحة الغذاء كوسائل جذب في رعاية كتاكيت الرومى فى التغذية المبكرة
}

\author{
محمه فرغلى علم الدين فرغلى \\ قسم إنتاج اللدواجن ـ كلية الزراعة - جامعة أسيوط ـ أسيوط ـ مصر.
}

تم استخدام عدد 180 كتكوت رومى بلدى عمر يوم غير مجنس لتقييم استجابة كتاكيت الرومى لغذاء مختلف الون و الر ائحة او التداخل

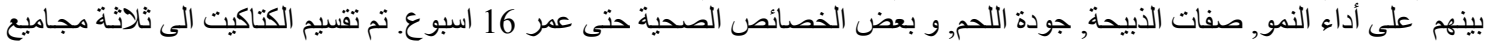

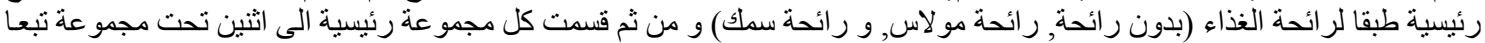

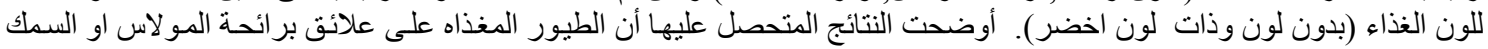

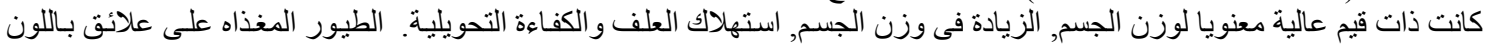

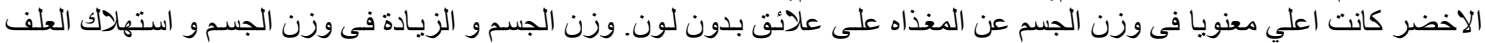

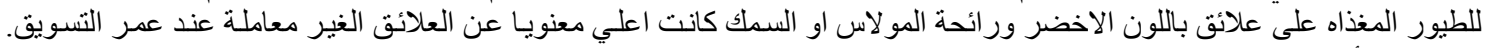

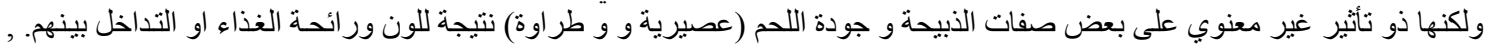

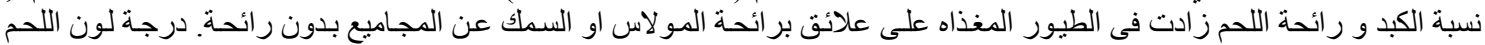

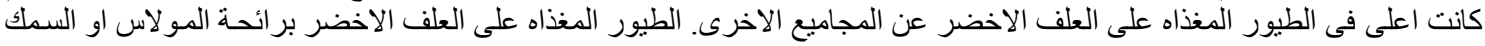

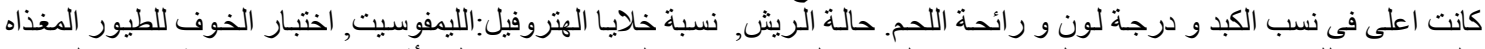

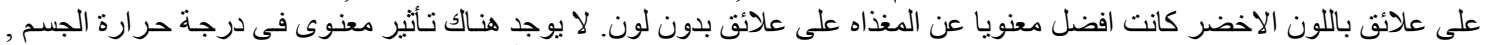

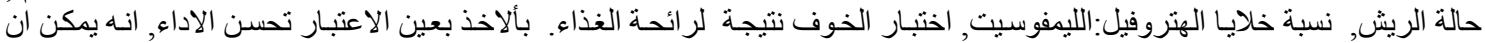

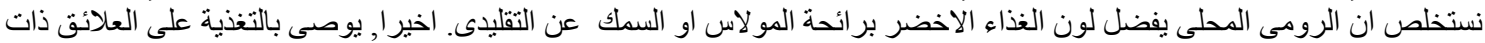

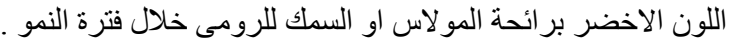

